\title{
A Study of the Effect of Privatisation on the Financial Performance of the Privatised Companies: A Case Study of Zimbabwe
}

\author{
Elliot Mugamu \\ Visiting Senior Lecturer \\ Centre for Entrepreneurship and Innovation Studies \\ Midlands State University \\ Senga Road, Gweru, Zimbabwe
}

\begin{abstract}
The literature on the financial performance of privatised companies in the developed and developing countries and also emerging markets is littered with both success and failure stories. This study which was undertaken to assess the effect of privatisation on the financial performance of privatised companies in Zimbabwe also witnessed similar scenario but with emphasis on improved performances. Data for this research were collected using selfadministered questionnaires and documentary analysis. 117 respondents were chosen using the stratified random sampling technique. The study revealed that privatisation resulted in enhancement of company profitability, improvement in company technology and increased employee welfare. However, there was no increase in the market share of the privatised companies. The post-mortem of damaging business practices at one of the privatised companies revealed that a series of strategic mishaps piled up and dragged the company into insolvency leading to its re-nationalisation by Government of Zimbabwe.
\end{abstract}

Key words: privatisation; performance; technology; benefits; market share; diversity; re-nationalisation

\subsection{Introduction}

The drive to privatise state-owned enterprises (SOEs) was influenced by their failure to operate efficiently. Like other developing countries, Zimbabwe witnessed SOEs which were unprofitable and failed to achieve their mandates and consequently stifled economic growth. This caused huge drain on government revenues which triggered, among other things, both domestic and external debt crises. Hence the intervention in the late 1990s by the international multi-lateral institutions: in particular the World Bank and International Monetary Fund (IMF) (when both realised that Zimbabwe's capacity to repay debt was seriously compromised) but without dictating the pace of privatisation in Zimbabwe. National debt repayment problems quickly emerged and it was not long before that period coincided with Zimbabwe's isolation from the international community. Sadler (1995) asserts that countries with strong privatisation programmes (as was the case with Zambia) experienced a rapid increase in foreign investment inflows that exceeded the inflows directly related to the disposals of SOEs to both locals and foreigners. Linked to this argument, a strong effort to privatise suggests that a country is open to private entrepreneurship and the authorities have signalled their willingness to accept and support private economic activity (Sadler, 1995). There is no doubt that Zimbabwe which has a responsibility to improve the livelihoods of her citizenry needs foreign direct investments and the privatisation programme would attract additional investors through signalling effects. No country can live in isolation.

Tanyi (1997) argues that privatisation facilitates the transfer of technology and also enables governments to improve their credit rating on the international market through debt-equity swaps. While it is legitimate to increase local investor base through privatisation, which must be encouraged because it promotes voluntary private market financing, the role and strategic importance of foreign investors must not be sacrificed. Added to this is the need for the presence and effectiveness of corporate governance structures. However, Mwandenga (1999) states that the only way in which many nationals in developing countries particularly in Africa can own the bulk of productive corporate assets is if national savings are increased and channelled into corporate ownership. For many years, Zimbabwe experienced liquidity problems making it difficult to save at both micro and macro levels.

Turning to the importance of good company financial performance, the researcher argues that a company has responsibilities to a variety of stakeholders including its shareholders, employees and customers. A key objective of the company must be to make profits (a financial return or reward that companies or entrepreneurs aim to achieve to reflect the risk that they take). That way, its future is guaranteed or jeopardised according to the satisfaction or lack of it. As pointed out by Brealey et al. (2017) it is not feasible to compromise on the financial objective in favour of secondary objectives. The achievement of profitable financial results attracts outside capital and management pays close attention to boosting profits because of the great importance placed on earnings in the market place. 
Company growth opportunities whether organically (through targeted markets or expanded operations) or by acquisitions are often created from profitable operations and businesses that understand the importance of profitability must always develop strategies that give them the best chance at remaining profitable (Merson, 2011). According to Kotler and Keller (2011) high trade profits within industry sectors can prompt competitors to enter the market.

The other reasons in support of the importance of good company financial performance are the ability to mobilise borrowings from financial institutions and attract investors and key competent employees. The quality of human capital in an organisation can be a source of competitive advantage. In running businesses companies in the private sector and also of late some SOEs, have profit targets and their management is incentivised for reaching them. The profit motive drives a free market economy and profitable operations perform useful functions of sending signals for changing levels of output of various products and for reallocation of resources. It is important to stress that companies cannot remain in business without turning a profit.

\subsection{Definition of privatisation}

A clear definition of privatisation used in this study is useful in order to give a full appreciation of the issues at stake because the concept was used in many different senses within the United Kingdom (UK) and also in many countries around the world. The definition in this study is the sale or transfer of state assets to the private sector for the purposes of reducing the size, scope and influence of government and the introduction of market competition (Abu Shair, 1997: Kay, 1987). Oyieke (2002) states that the development of privatisation was expected to improve profitability, growth, solvency, liquidity and efficiency in privatised entities. The experience of International Finance Corporation (IFC) as an investor in privatised companies showed that the companies in almost all cases improved the economic performance of previously state-owned assets (Kaffenberger, 1995).

\subsection{Background of the study}

In Zimbabwe, privatisation is a phenomenon for the mid-1990s and its acceptance and temporary adoption by the Mugabe's administration could well have been a reactionary strategy to tackle the failure of previous socialistbased policies that were adopted at independence. Contrary to expectations, the privatisation programme has not gathered momentum and according to Godana and Hlatshwayo (1998) it does not display a good record at both aggregate and sectorial levels. In this regard, between 1997 and 2012, the Government of Zimbabwe (GOZ) privatised five SOEs. These are Dairy Marketing Board (DMB), Cotton Marketing Board (CMB), Commercial Bank of Zimbabwe (CBZ), Zimbabwe Reinsurance Corporation (Zimre) and Rainbow Tourism Group (RTG). DMB, CMB and CBZ on one hand and Zimre and RTG on the other, were privatised in 1997 and 1999 respectively. Upon commercialisation DMB and CMB were rebranded to Dairibord Zimbabwe (Dairibord) and Cotton Company of Zimbabwe (Cottco). Compared with privatisation programmes and trends in many developing countries including Zambia, a neighbouring country, coupled with the high number of SOEs in Zimbabwe at about 103 after privatisation, the number of privatised entities at 5 is too small and also very insignificant representing a mere five (5) percent of the total population.

However, following the commencement of the land reform programme in 1999 code named 'Fast Track' (Makadho, 2006), Zimbabwe went through a decade of recession between 1999 and 2008. But the introduction of the multi-currencies in the economy on 29 January 2009 followed by the formation of the short-lived but stabilityinducing coalition government in the first quarter of 2009 between Zimbabwe African National Unity Patriotic Front (ZANU PF) and the two-Movement for Democratic Change (MDC) formations halted consecutive years of gross domestic product contraction. Ramamurti (1992) notes that privatisation is more likely to be pursued by countries with the characteristics such as high budget deficits, high foreign debt, portfolio of perpetually loss making SOEs and high dependence on international agencies like the World Bank, IMF, Paris Club, African Development Bank and African Export and Import Bank. Zimbabwe is no exception to these characteristics. In fact, during the four year tenure of the coalition government to 31 July 2013 the issue of privatising SOEs in Zimbabwe was never brought up for discussion. The MDC formations did not have the appetite for privatisation let alone discuss the concept even though the Finance Ministry portfolio was held by the opposition. The advent of the inclusive Government made it almost impossible to police public institutions as appointments and oversight responsibilities were being done on partisan political lines. Hence to some extent, the situation that Zimbabwe now finds itself in with regard to the continued poor performance of SOEs is a result of those economic, social and political factors.

Sadly, the pace of privatisation in Zimbabwe remained static. According to White and Bhatia (1998) the pull and push factors leading to privatisation differ across countries. However, Chirwa (2001) points out that in most African countries the policy of privatisation is associated with the World Bank and IMF sponsored economic structural adjustment programmes. 
This lack of progress in the privatisation process of SOEs in Zimbabwe could signal concerns at government policy level. Hence, the academic interest by this author to carry out a research study of the effect of privatisation on the financial performance of the privatised entities in Zimbabwe.

\subsection{Statement of the problem and objectives of the study}

The main aim of privatisation is to enhance the performance of privatised firms. Despite the GOZ having started the privatisation programme in 1997 and as pointed out under the sub-heading 1.2, only 5 companies were privatised in Zimbabwe. This very low figure compares to over 254 SOEs that were privatised in Zambia by 2002 (World Bank, 2002). A critical analysis of the events in Zimbabwe raises fundamental questions about the performance of those very few privatised entities. How have they performed during the post privatisation period? To what extent has the performance of the privatised companies affected the government's position of not implementing the privatisation programme on a large scale? It is against this background that the researcher identified the area of carrying out a comparative analysis of the performance of privatised public enterprises in Zimbabwe to be of academic interest.

This study was undertaken with four specific objectives as follows:

a) To establish the effect of privatisation on the profitability of the privatised SOEs in Zimbabwe.

b) To analyse the effect of privatisation on technology advancements of privatised SOEs in Zimbabwe.

c) To determine the effect of privatisation on the market share of privatised SOEs in Zimbabwe.

d) To find out the effect of privatisation on the welfare of employees of privatised SOEs in Zimbabwe.

The research sought to assess any lessons learnt on both success and failed stories relating to the financial performance of privatised entities in developed and developing countries and also emerging markets particularly those with different economic and political conditions.

\subsection{Managing conflict of interest}

At the commencement of the studies, the researcher was already a non-executive director (NED) of both CBZ Bank and CBZ Holdings [the listed entity on the Zimbabwe Stock Exchange (ZSE)]. There is no doubt that the researcher would have been conflicted if he had undertaken a study of this nature on CBZ Group but at the same time remained on both boards even though he was just a NED. In order to avoid any possible conflict of interest, the researcher excluded from the study CBZ Holdings, a creation from CBZ Bank-a privatised entity and focused on the remaining four privatised companies.

\subsection{Delimitations of the study}

The researcher defined the boundaries of the study and this approach is supported by Paechter (2013). The delimitating characteristics comprised four of the five SOEs that were privatised between 1997 and 2012. It is publicly acknowledged that Zimbabwe went through a very difficult hyper-inflationary period between June 2002 and January 2009. Inflation adjusted figures could have been used for analysing and assessing the effect of privatisation on the financial performance of the privatised firms. However, Zimbabwe's high inflation figures at that time found themselves a place in the world economic history because they were beyond reach. From a practical view point, the researcher found it necessary to exclude this period from the analysis of data.

Consequently, the study focused on the 6 year period from 2009-14 (a period covered by dollarisation within the economy) in order to get a clear view of the effect of privatisation on each entity's financial performance and also to highlight any movements in the ratios that required explanation or investigation. The researcher felt that it was improper to judge the effect of privatisation on privatised companies on the basis of a single year's figures.

\subsection{Literature Review}

This section focused on the literature review relevant to the study. It was based on the UK, Zambia, Kenya, Seychelles and Pakistan: countries the researcher believed made significant progress in the privatisation drive and that had been the subject of scholarly research. The UK is the forerunner of the massive privatisation programme (Pettinger, 2013). The countries analysed in this literature review were selected both for the scope and impact of their privatised entities. For example in Southern Africa, Zambia responded very early to the call by the international community to phase out state control and ownership of economic activity. On the other hand, Zimbabwe which is predominately the subject of the study was very slow in responding to pressure from the same source. However, the review allows for a subsequent analysis of the performance of privatised firms in Zimbabwe.

\subsection{Review of the performance of privatised companies in the UK}

The literature review on the effects of privatisation on the financial performance of privatised entities in the UK focuses on British Telecommunications (BT), British Airways (BA) and National Freight Company. 
Vickers and Yarrow (1997) report that the first large privatisation in the UK was on BT in 1984 and according to Saunders and Harris (1994) its disposal set the style and tone for subsequent privatisations. The primary objectives of privatising BT were to improve company performance coupled with opening up the telecommunication market to competition. Both objectives were met. Service delivery levels greatly improved, operational efficiencies rose and consequently the company met its financial targets. Initially employment levels fell considerably but rose following business expansion and new investment (Saunders and Harris, 1994). Jones (1994) states that the performance of BT's post privatisation period is a case in which the release of investment constraint was a major source of the gains from privatisation as new investments in technology reduced the high costs to consumers. BT is a privatisation success story. The company's continued achievement of strong financial results enabled it to successfully move into newer high technology markets and cutting broad band charges to compete with its private sector rivals.

What distinguishes the BA's case from other cases is the long time between the divestiture announcement in 1979 and its consummation in 1987 (Vogelsang, 1994). BA was an attractive candidate for privatisation because it was profitable and a change in its ownership raised far fewer problems (Vickers and Yarrow, 1997). However, the privatisation of BA raised two important questions about competition and regulation. There were fears in some quarters that the privatised airline would exploit its dominant position more energetically in the private sector. The birth of Virgin, which became and remained a formidable competitor and many others, did put people's fears to rest.

The performance of a privatised BA is often regarded as a success story because of various significant strides that were achieved in terms of four points: first, sustainable profitability of the airline. Company profits climbed from GBP162 million in 1987 to GB 580 million by 1999 reflecting an increase of two hundred and fifty eight (258) percent over a twelve year period after privatisation (BA Case Study and BA's Annual Reports, 1983-99). The study carried out by Eckel, Eckel and Singal (1997) affirmed that privatisation of BA improved economic efficiency by reducing employment and increasing productivity. Second, was the growth in the airline fleet. Third, payments of corporate and value-added taxes to the Inland Revenue were recorded. Fourth, employment generation opportunities were witnessed in downstream industries.

In the British history of privatisation, National Freight Corporation (rebranded to NFC after privatisation), was the most well-known case of management and employee buy-out (Vickers and Yarrow, 1997: Saunders and Harris, 1994). Before privatisation NFC had a record of poor financial performance and following its privatisation, the company's performance greatly improved. Saunders and Harris (1994) report that company profits for the first year after privatisation rose by fifty (50) percent and by a further seventy (70) percent the year after. This remarkable position is also supported by Letwin (1988). Upon public listing on the London Stock Exchange on 25 November 1988, the company's share price moved upwards 73 folds from 2,5 pence to 185 pence (Grout, 1999). Although it is hard to believe, Vogelsang (1994) asserts that all the increase in value and performance of the business arose from the impact of the change in ownership.

\subsubsection{Failed cases of privatised entities in the UK: water, railways and financial institutions}

The literature on the effects of privatisation on the performance of privatised companies in the UK has cases of privatised entities whose performance levels were disappointing. Examples of failed cases include those in the water, railways and financial sectors. Bradshaw (2000) argues that the improvements in the financial performance within the rail and water sectors, though very temporary, were not due to increased internal efficiencies and processes but largely due to deterioration in service delivery standards underpinned by lack of maintenance and infrastructure development.

According to Lobina and Hall (2001)within a few years of privatisation, privatised water companies which served London were unpopular with consumers because of excessive pricing, excessive industry profits by international standards, reduction in capital investments (in order to maintain high dividend pay-outs, excessive remuneration packages for management and high levels of directors emoluments) and disregarding environment and pollution issues. Saunders and Harris (1994) point out that contrary to expectations the privatisation of the water authorities in the UK did not create any competition. The researcher therefore supports the view held by Vickers and Yarrow (1997) that privatisation of firms must be undertaken in reasonably competitive industries. Mwandenga (1999) argues that the privatisation of natural monopolies such as railways, water supply and electricity does not change the inherent monopolistic characteristic of such industries.

Very notable cases of failed privatised entities in the financial services sector in the UK are Northern Rock and Royal Bank of Scotland. When the signs of difficulties and distress emerged in those two institutions, the British Government moved in swiftly to re-nationalise them thereby coming to the rescue of the general public and investors (The Economist, 2007). 


\subsection{Financial performance of privatised companies in selected African countries}

Jerome (2004) reports that although privatisation as a programme has been relatively less successful in Africa than elsewhere, the continent was not left out in the race to sell off state enterprises. There are a number of good examples of privatised companies in African countries that crossed the bar of financial success and are highly regarded as being the success stories behind privatisation. However, Mutugi and Ngugi (2013) point out that where privatisation took place, varying degrees of success and failures with the performance of privatised entities were recorded. The researcher focused on experiences in Zambia, Kenya and Seychelles in that order.

\subsubsection{Performance of privatised companies in Zambia}

Zambia has a fair share of successful companies and the list of success stories came from agriculture, manufacturing and tourism sectors. Some of the names that made it to the list include Zambia Sugar, Chilanga Cement (now rebranded to Lafarge), Zambia Sugar, Intercontinental and Tata Hotels and Zambia Breweries (Chipwende, 2001: World Bank, 2002). The decline in employment in the privatised entities was to be expected as most companies had bloated staffing levels. The new shareholders of the privatised companies not only capitalised them but also invested in new technology (bearing in mind that the companies had been struggling for some years). Additional support for the ventures through massive investments in marketing, supply chain management and logistics, financial and technical resources helped the privatised companies to record significant growth rates in their financial performance. Organisational culture change was the most difficult to implement but it was done by bringing into the country expatriate labour from the SADC region, India, Canada, China and the UK at very senior levels within the privatised entities to impart knowledge and bring about increased productivity to the Zambians (Chipwende, 2001). Drastic cost containment strategies were implemented across the value chains. Lubansa and Mofya (2005) report that social services such as pre-schools and hospitals previously provided at the copper mines were discontinued much to the annoyance of the local communities. As part of their product development strategies, some of the privatised companies introduced new products that found export markets in Democratic Republic of Congo, Malawi and Zimbabwe thereby generating foreign exchange.

When Zambia analysed all the companies that were privatised and their subsequent fortunes (misfortunes) it is often reported that those that were only partially privatised with government retaining some shareholding fared worse than those that were fully privatised. According to Chipwende (2001) the shadow of government and its possible influence on the affairs of the companies posed operational challenges which impacted negatively on corporate profitability. This position is very much similar to one of the characteristics of privatisations in China in which Chen et al. (2000) assert that the state tends to control over fifty (50) percent of the issued capital. In that scenario the privatised company can have autonomy and operate in competitive markets.

However, in practice the Chinese government through its majority stake can vet management decisions and influence management to take courses of action which advance social and political objectives that may be detrimental to the achievement of corporate profitability (Chen et al. 2000).

\subsubsection{Zambia's failed cases of privatised entities}

Whilst there appears to be a number of lesser privatisation successes, most of those involved were smaller companies that were sold to management buy-outs and Zambian individuals. The varied reasons for the poor financial performance included: lack of capacity to raise and mobilise long and short term financing to undertake new capital investments and for working capital purposes, the lack of new technology and market development strategies coupled with the low entrepreneurial and management skills, the inability to adapt to the new competitive environment prevailing in Zambia against the backdrop of a liberalised market and the significant indebtedness and large losses carried from the parastatal era. A point worth noting is that the failure rate of privatised companies in Zambia was less than three (3) percent which was considerably lower than that of Eastern Europe which ran at over twenty (20) percent (Chipwende, 2001). There was no evidence to indicate that the failed companies would not have failed had they remained state-owned. It is quite possible that they could have been closed down earlier. In the modern world, it is normal for some businesses to succeed while others will always fail. But in the competitive business environment it is often the survival of the fittest.

The privatisation and re-nationalisation of the national Zambia Telephone Company (Zamtel) were invariably controversial given its size and strategic importance to the Zambian authorities. Hence the developments at that company deserve special mention. This is a company that was privatised in 2010 to the Egyptians and then renationalised in 2013. The effect of its privatisation improved the financial performance. Upon its re-nationalisation, Zamtel went back into loss making position. The events tell a big story about the positive effect of privatisation on the financial performance of a privatised entity. 


\subsection{Performance of privatised companies in Kenya}

In Kenya privatisation was undertaken to accelerate Africanisation of the economy (Tangri, 1999). According to Deloitte (2011) over 140 former SOEs companies which were earmarked for privatisation by the government of Kenya were privatised and financial ratios for the post privatisation period indicate that the performance improved. The negative impact of the financial losses incurred by Kenya Airways (KQ) before privatisation together with the need for its survival presented the opportunity to drive change at the national airline. Burnes (2004) asserts that the need for change may originate from different sources: both inside and outside the organization. The privatisation and listing of KQ on the Nairobi Securities Exchange in 1996 was the first-ever privatisation of an African Airline. It is for this reason that the researcher briefly reviews the financial performance of the privatised airline.

The airline's CEO was picked from the private sector to lead the management team in the privatisation effort. That in itself was critical because the CEO did not bring with him any bureaucratic baggage normally associated with those from the public sector. Naikuni (2004) asserts that the press and public of Kenya speculated as to how and when the privatisation process would fail and which interest group would profit from that failure. McKenna (2001) points out that the airline went through a massive restructuring exercise in order to introduce accountability, competitive market forces and economic efficiencies into its operations. The effect of privatisation on the financial performance of KQ provided an African success story. The airline recorded strong financial results that enabled it to invest in aircraft fleet thereby creating increased route network on the domestic, regional and international markets (Ford, 2013). The success of KQ is often quoted as an example of efficient leadership (Massey, 2010: Debra and Toroitich, 2005).

However, in the last four years from 2012-15, Kenya witnessed a major decline in tourist arrivals from its traditional strongholds in Europe, Asia and the Americas. This followed Islamist terrorist attacks in key holiday resorts, major shopping centres in Nairobi and Mombasa and other areas. Rivers (2015) argues that had the terrorist incident been a one-off, it would have had a muted impact on tourism. Consequently, international tourists sidelined Kenya as a holiday destination and this development had a major negative impact on KQ's financial performance. In its financial year ended 31 March 2015 KQ posted a loss of about USD254 million and this was the worst financial result in the corporate history of its post privatisation. The sheer scale of the losses caused airline management to face an uphill struggle to convince politicians and the public that they deserve another shot at commercial viability. Yin (1994), Van der Hoeven and Sziraczki (1997) and Kamoche (2001) all argue that it is appropriate and necessary to use case studies in highlighting success stories and to illuminate our understanding of the benefits of privatisation.

In this regard, KQ is certainly a good case study. However, until its problems of the past few years surfaced, the airline was regarded as a model of successful privatisation after its listing in 1996 turned it into a profitable company. Studies carried out on 79 privatised firms from 21 countries by Boubakri and Cosset (1998) concluded that there were significant improvements in the operating performance of those companies and the development at KQ concurs with the findings of these two authors. However, in their analysis of data on 500 large privatised firms, Dewenter and Malatesta (2001) found that earnings improved after privatisation but declined subsequently.

This affirms the development at KQ but the impact of terrorism threat on the business is a matter beyond the management of KQ. The analysis of the effects of privatisation on performance of privatised SOEs listed on the Nairobi Securities Exchange carried out by Mutugi and Ngugi (2013) revealed that their profits were aided by good corporate governance which was the key to the operational activities. In Kenya, management performed better after privatisation and the absence of conflict between management and stakeholders in particular the board was an important determinant of improved performance for privatised firms.

\subsection{Performance of a privatised entity in Seychelles: Air Seychelles}

Upon the privatisation of Air Seychelles in which Abu Dhabi carrier Etihad Airways (Etihad) took a forty (40) percent stake followed by the appointment of a new CEO (an ex Etihad official), Seychelles flag carrier reported a profit of USD3,2 million in 2014. According to Gulf Business (2016) this was Air Seychelles' third consecutive profitable year since the investment by Etihad. Since its privatisation which rationalised staffing levels and operational activities, Air Seychelles remained focused on extracting maximum value from its modern fleet and expanding regional and international network which it had to grow strategically with new destinations and trusted code share partnership. One interesting development which must be mentioned is that the board of directors of Air Seychelles is chaired by the country's Minister of Foreign Affairs and Transport (Gulf Business, 2016). In other African countries, this position could have been an open invitation to political interference thereby impacting negatively on the performance of the privatised entity. However, turning to corporate governance tenets around international best practices, this development could easily raise issues pertaining to conflicts of interest. 


\subsection{Performance of privatized companies in Pakistan}

While privatisation was implemented in many industries, in Pakistan overall the programme was a great success in terms of survival of some of the privatised firms, improved financial performance, increased capital investment and technology, increased employment levels in down-stream industries and enhanced employee welfare and welfare facilities (Francies and Tufail, 1998). The added employee benefits from the privatised firms really motivated the workforce. Change of management rather than change in demand or competition was the main contributory factor to the improved financial performance. Andreff (1997) argues that the first basic performance criterion to be assessed is the impact of privatisation on the company's profitability. The positive social impact on consumers in Pakistan involved increased availability of value for money goods and services, creation of profitable markets for both small scale and large commercial farmers and increased promotion of economic growth which in turn was fundamental in alleviating poverty. Value creation for the shareholders and related stakeholders including the general public was a positive development that persuaded the Government of Pakistan to consider the privatisation of the flag carrier, Pakistan International Airways. For the privatised companies that did not do well, Francies and Tufail (1998) in their final report on the Impact Analysis of Privatisation in Pakistan, noted that the reasons for their poor performance were bad management, failure to respect corporate governance structures and absence of hands-on approach to management as some of the businesses were run by remote control from outside the country.

\subsection{Conceptual and Theoretical Framework}

This section highlights factors that are important to understand why privatisation policies have been pursued and what impact they have had. The intention is to provide the framework for understanding the current experiences of privatisation in Zimbabwe.

\subsection{Theoretical framework}

According to El-Rufai (2012) the active participation of government in business has a long history dating back to hundreds of years. Publicly owned enterprises were therefore seen as hybrids combining the efficiency of commercial entities with the social conscience of government in that they were used to promote economic development, tackle monopolistic abuses in strategic areas such as railways, airline, water and telecommunication where the magnitude of investment was beyond the capacity of the domestic sector. Miller (1997) argues that the rapid growth in the number of SOEs in the developing world particularly in countries which had recently attained independence was attributable to tradition, ideology, patronage and practical considerations. For example, in Tanzania between the mid 1960's and the late 1970's the number of SOEs increased from 50 to 400 (Mwandenga, 1999). During the colonial period, foreign governments owned and controlled many of the businesses in their colonies. Upon the granting of independence, the former colonies preserved this tradition of government control by assuming ownership of these businesses because they had mistrust about the private sector and also disliked foreign ownership.

As a reactionary strategy to the capitalism of the former colonial powers, state ownership was also supported by socialist ideology following its adoption. Many developing countries believed that state ownership was necessary to preserve economic independence in the face of the perceived threat of neo-colonialism (Miller, 1997). During Zimbabwe's first democratic elections held in 1980, ZANU PF campaigned vigorously on a policy of nationalisation and more equitable income distribution.

At her independence in 1980 Zimbabwe, like all other African countries, inherited from the colonial government various forms of state economic intervention. During the first few years of independence, the country witnessed a marked enlargement in its SOEs sectors because the GOZ strongly believed that the state had a central role to play in directing the development process. The idea was that various large and strategic industries having public rather than private ownership would serve the public interest better by virtue of their accountability to the people through a board of directors appointed by the government, accountable to the line Minister and in turn to Cabinet and then Parliament. The policy statement of empowerment and accountability made a lot of sense. The Zimbabwean government also believed that private capital in its own country, which was largely and is still owned by the white people and to some extent Asians, was and is an important source of political and economic power. In that regard it was critical that the power be put in the hands of an elected government for the primary purpose of protecting the country from having its policies dictated by large private sector firms. Godana and Hlatshwayo (1998) argue that lack of indigenous entrepreneurship with adequate capital and skills, severe regional and sectorial imbalances and highly skewed distribution of wealth motivated the role of the state in direct economic activities outside infrastructural development. 


\subsubsection{Nationalisation theory: enlargement of public enterprises sector}

By 1984 state-owned industries and companies had been established in Zimbabwe in almost every sector of the economy including agriculture, banking, transport, insurance, mining, hospitality and even retailing of books, stationery and periodicals. Nellis (1994) points out that SOEs established in most developing countries were without sufficient reflection, clear objectives and sound economic and financial feasibility studies. No wonder why their performances were disappointing (Megyery and Sader, 1996). The nationalisation programme in Zimbabwe was a development that was contrary to the winds of change in the western world particularly in the UK under Thatcher's premiership. In some cases these developments were undertaken with the understanding that commercial viability was not absolutely guaranteed but the locations and activities were justifiable on the basis of overall development of the area. That development touched the lives of virtually every person in Zimbabwe. Consequently, the government embarked on transforming the national economy into a socialist state and admittedly considerable social progress was made in the areas of education, health and smaller holder agriculture. Blair (2002) points out that Zimbabwe's massive expansion of education and health services was hailed as a model for other African countries. Over the same period, literacy rose to over ninety two (92) percent of the adult population, one of the best records in Africa after Tunisia (Blair, 2002). Those positive social developments reinforced the appreciation by Zimbabweans (in particular those previously disadvantaged communities) of living in an independent country. According to Blair (2002) all of these real achievements were undermined by mismanagement of the economy to the extent that better educated and healthier Zimbabweans were becoming poorer. Little did they know that Zimbabwe would go through severe economic challenges and lose her status as the bread basket of Africa (Blair, 2002). Unfortunately, things have not changed for the better.

\subsection{Conceptual framework}

Unfortunately for the GOZ the social progress attained was not matched by economic growth and rising per capita income. The poor financial performance of SOEs worsened and direct subsidies to them (the loss-making institutions such as National Railways of Zimbabwe (NRZ), Grain Marketing Board (GMB), CMB, DMB and Air Zimbabwe to name a few) showed upswings thereby impacting negatively on the fiscus. Pressure increased on the national budget forcing the government to borrow heavily from both the domestic and external markets.

Sadly, interest rates and inflation markedly shot up. Unemployment levels across the national spectrum rose sharply to unprecedented levels. Price controls and massive shortages of foreign exchange caused havoc on the economy. As economic and social difficulties mounted, the GOZ abandoned in 1989 the long road to socialism much to the approval of the general populace and began to implement market reforms through an economic structural adjustment programme (ESAP) in line with the conditions set by the World Bank and IMF. It is often stated that the GOZ was warned that it would take some years of hardship and painful structural reforms before the country returned to anywhere near its level before ESAP (Godana and Hlatshwayo,1998).

The unfortunate thing about the events in Zimbabwe is that when the privatisation was put in motion in 1997/99 the general public did not fully understand it as the programme was viewed as a directive from the international community to secure additional funding and lines of credit. It is the researcher's view that there was need for vigorous public education-out-reach programmes and road shows countrywide.

The researcher supports the view that the acceptance of economic prescriptions from the IMF and World Bank could have been an admission and realisation by the GOZ that it had been wrong not only to discourage private and foreign investments but also to keep a blind eye on public sector reforms. Skalnes (1995) argues that ESAP based macro- economic policies were intended to curb excessive and irrational state intervention and to counter state corporatism which repressed the participation of civil society in policy making. According to Young (1995) the ESAP's initiatives directed by both the Bretton Woods Institutions included privatisation as an important policy measure. This view is also supported by Cook and Uchida (2003) when noting that seventy (70) percent of all structural adjustment loans made during the 1980s contained a privatisation component. Most African countries reluctantly accepted or were made to accept the policy of privatisation but very few pursued this policy vigorously with the exception of Ghana, Gabon and Zambia (Godana and Hlatshwayo, 1998).

The GOZ continued to face strong political resistance in the area of privatising SOEs despite the perceived advantages of the programme. The resistance manifested itself in that between 1997 and 2012 only 5 SOEs were privatised, an issue already mentioned under sub heading 1.2.Tanyi (1997) points out that there is no perfect divesture technique and each of the techniques brings benefits and risks. Zimbabwe used one method which was the sale of state assets through initial public offering (IPO). Meggison et al. (2004) report that IPO is sometimes viewed as a tool for promoting local stock exchanges especially in developing or emerging economies and privatisation through IPO also promotes corporate governance structure, which creates prospects for better post- 
privatisation performance. The decision to privatise Dairibord, Cottco and RTG was based on government's disappointment with the actual performance of these.

With regard to CBZ and Zimre which were profitable before privatisation, the government perceived that the lure of financial incentives and the discipline of the capital markets would spur greater efficiency. Some people mainly from the political arena argue that the continued delay in the full scale privatisation process during the hyperinflationary period from 2002-09 worked in favour of the GOZ because investors (whether foreign, local or both) could have picked government assets very cheaply because the local currency was under extreme pressure from massive devaluation against major trading currencies. However, privatising 5 public enterprises over a 17 year period is in itself a worrying development particularly when this position is at variance with trends in other developing countries, let alone in African countries. It is also disturbing to note that key SOEs such as GMB, Air Zimbabwe, NRZ, ARDA and many others which remain plagued by operational inefficiencies, corporate governance challenges and political interferences have neither been privatised nor earmarked for privatisation. Run effectively and efficiently SOEs can have huge positive impact on economic growth. Prior to the introduction of multi currencies in late January 2009 acute shortage of foreign exchange in the country was often used as one of the key reasons for the poor performance of public enterprises. The government failed to manage, monitor and demand accountability for the operations of the SOEs: factors that caused their poor performance leading to huge financial losses, inefficiencies and lack of service delivery.

There are arguments and counter arguments regarding the privatisation of profitable and loss making entities. Selling off loss making enterprises fits well with the fiscal objective of privatising to reduce the budgetary burden imposed by the continuation of such enterprises. It also puts into test other fundamental arguments of privatisation that private ownership is more efficient than public ownership. On the other hand, private investors might not be interested to take over failed enterprises. And if they do (as was the case with some of the copper mines in Zambia), they could ask for certain privileges, exemptions, protection and subsidies thus hindering the creation of competitive environment necessary for privatisation. However, the sale of profitable and sound enterprises could attract many potential investors, provide strong impetus to privatisation, generate and strengthen faith in government privatisation programme and augment the proceeds of the programme. But this line of argument raises a fundamental question.

Why sell the few of the best and good enterprises? If this argument is to be accepted, then this move undermines the privatisation programme itself. Furthermore, selling profitable companies while the deficit ones remain within state ownership will only augment the fiscal difficulties and budget deficit since such a sale will deny government stream of future revenues. Egypt chose to sell the profitable companies first, while Tunisia began with the loss making ones. Sudan and Morocco used both approaches (Abu Shair, 1997).

After privatisation each company was listed on the ZSE. In Zimbabwe privatisation did not bring about immediate changes in senior management. After six years post privatisation, Cottco and RTG replaced their CEOs through internal candidates-signalling well managed succession plans. Zimre's CEO retired after a 31 year service with the same company. At the time of going to press the CEO of Dairibord is still in the office.

\subsection{Research hypotheses}

From the conceptual framework, the four hypotheses that were tested using T-test and F-test were:

1) Ho - Privatisation of SOEs has not increased company profitability.

H1 - Privatisation of SOEs has increased company profitability.

2) Ho - Privatisation of SOEs has not advanced company technology

H1 - Privatisation of SOEs has advanced company technology

3) Ho - Privatisation of SOEs has not increased employee benefits.

H1 - Privatisation of SOEs has increased employee benefits.

4) Ho - Privatisation of SOEs has not increased company market share.

$\mathrm{H} 1$ - Privatisation of SOEs has increased company market share.

\subsection{Operationalisation of the hypotheses}

The researcher identified four independent variables arising from the effect of privatisation on the financial performance of privatised SOEs: enhanced profitability, improved technology, improved employee benefits and greater market share. However, risk management was not considered as a variable as it cuts across all the four variables within the companies' value chains. 


\subsection{Research Methodology}

The research study used both the qualitative and quantitative approaches because the focus was on in-depth interviews and documentary analysis. The quantitative method was taken on board on a limited scale to deal with the population and sampling issues and this approach is supported by Onwuegbuzie and Leech, (2007). According to Bernard (2013) and Ary et al. (2002) the most important characteristic of a sample is its representativeness not its size of the population. The participants were made up of current and former: minister/board member/senior management; middle management/shop floor employees; business people/politicians; who had intimate knowledge about the privatised companies. Robinson (2014) and Yin (2009) assert that purposeful sampling strategy in qualitative studies enables the researcher to gain deeper insights and collaborative sources of evidence from knowledgeable respondents. Suri (2011) states that the respondents must have genuine experience needed to provide useful data. The stratification approach was used as a means of reducing sampling error. The researcher stressed to the participants that the research was independently financed and it would not attempt to question management and board decisions, neither would it improve the working conditions and employee benefits nor would it bring about opportunities for funding and employment creation. More importantly, the discussions were absolutely confidential.

Fitzroy et al. (2012) argue that the firm's accounting system is the primary source of information for assessing a firm's financial performance. It is through this understanding that the secondary data were extracted from the audited annual reports of the privatised companies. As stated elsewhere in this article, the key performance indicators included profitability, operating efficiency, liquidity and gearing ratios. In order to enable comparison, data were analysed through the use of descriptive statistics and ratios. By way of a cautionary statement, ratios with large deviations from the norm merely indicate symptoms of a problem (Gitman, 2006). Added to this challenge is the fact that a single ratio does not generally provide sufficient information.

Data on the firms' past five year history before and after privatisation would have helped to build up a picture of the development patterns. However, the time frame from 2002 to 2008 reflected a period of severe economic challenges in Zimbabwe involving hyper inflationary forces and that period was left out as inflation had a material impact on the financial results. Summary audited financial data were collected and analysed for each of the privatised entity from 2009-14 and this provided an extended longitudinal perspective of financial performance. To minimise any probable errors, only audited accounting data were used in this study by the researcher.

\subsection{Presentation of the Findings and Analysis: An introduction}

The presentation of the research findings is covered under two sections. The first section deals with the analysis of the findings from the primary data on the performance of privatised companies. The second section focuses on survey results from the secondary data analysis. The results of the study per discussed statistical analysis are collaborative of the findings of the research using secondary data.

\subsection{Sample size and participants' understanding of privatisation}

Data were drawn from 117 participants from the four privatised companies chosen using the stratified random sampling and the Statistical Package for Social Scientists (SPSS) version 21.0 was used to produce meaningful information from the raw data gathered from the self-administered questionnaires. A total of 11 potential participants declined to be interviewed giving a response rate of ninety one (91) percent. Ninety eight (98) percent of the respondents who participated in the survey had knowledge about privatisation. The study sample was therefore deemed knowledgeable enough for the researcher to draw meaningful conclusions from the survey.

\subsection{Distribution of participants from the privatised companies}

The participants were drawn from the four privatised entities: Dairibord, RTG, Cottco, and Zimre. The majority of participants at thirty six (36) percent were drawn from Cottco. The company was selected on the basis that it is one of the largest foreign currency earners in the agricultural sector in Zimbabwe and the researcher had a keen interest in knowing performance details of Cottco arising from its significant impact on over 300000 rural communities in seven out of Zimbabwe's ten provinces. The participants from Zimre, Dairibord and RTG comprised twenty four (24) percent, twenty one (21) percent and nineteen (19) percent respectively of the total sample. The middle management and shop floor employees at forty (40) percent constituted the majority of the surveyed participants followed by minister/director/senior management and business people/politician at thirty three (33) percent and twenty seven (27) percent respectively.

\subsection{Method of privatisation used}

Respondents were asked whether the privatisation method of IPO, which met the listing requirement of the ZSE, used by the GOZ to privatise its SOEs was the most appropriate. The majority of respondents at eighty seven(87) percent affirmed the position. Three (3) percent were indifferent to the question and ten (10) percent were not sure. 
Sale of public enterprise shares to the general public in the open market have both positive and negative consequences many of which are not really intended. For example, hostile foreign buyers (fronted by locals) could have entered the market, bought shares and raised problems for public policy and management and losing control of the business to foreign corporation. This is definitely a security issue that could have undermined the economy.

\subsection{Other privatisation methods the GOZ could have used}

Thirty eight (38) percent stated that capital dilution and joint venture (CDJV) was another privatisation method, while the same percentage of respondents disclosed that the GOZ could have used other methods including management/ employee buy-out, build-own-operate and transfer and public private partnerships. Fourteen (14) percent of the respondents preferred CDJV because they felt that somehow the government should remain with a significant shareholding in the privatised companies. The shadow of government was meant to give some sense of security a view not shared by the researcher because in Zambia and South Africa partially privatised firms in which the state had significant shareholding or is still in control are worse off in terms of profitability or raising funding from the market than complete privatisation. In comparing the privatisation methods used in Zambia and Zimbabwe, Haley (1999) states that the sale of the business (the privatised company) rather than shares (as was the route used in Zimbabwe) could have raised a better price for the seller, the government.

Because of change of ownership, the Zambian method of disposal brought about new management changes whereas the Zimbabwean approach paved the continuation of the same management from the parastatal era. However, the government derived its comfort of using the same management from their individual contribution to the success of the companies during the commercialisation period.

Although measures were put in place to broaden ownership through employees' participation and management buy-out, the majority of people in Zimbabwe are generally poor and do not have significant savings to participate in the ownership structure of the privatised companies. With the exception of Dairibord employees, the researcher found that workers did not care who owned the privatised businesses. What the employees really wanted to see was a professionally, competently and efficiently run firm whose future would guarantee job security and wages for them. In some cases the hope that employee shareholding released a new entrepreneurial spirit throughout the workforce was undermined by the intensification of some workers' traditional concerns about job security, payment of bonus and wage bargaining deals. The belief that share ownership fostered strong vertical bonds between the workforce and management is supported by Saunders and Harris (1994).

\subsection{Attainment of financial performance targets}

Figure 5.1 shows the percentage distribution of the attainment of financial performance targets. Fifty (50) percent of the respondents reported that financial performance targets were met by the privatised companies. The research findings showed that only thirty five (35) percent of the respondents reported that the privatised companies did not meet their financial targets as opposed to fifteen (15) percent who reported that there was a mixed financial performance on targets.

\subsection{Major driver for financial performance}

The research findings showed that forty three (43) percent of the respondents believed that the major driver for the financial performance of the privatised firms was due to visionary leadership, while thirty five (35) percent believed the board and management had the freedom to manage their businesses distanced from the political process. In many ways there was psychological pressure that the CEOs were heading the first batch of privatised companies. Hence it was critical for their organisations to perform beyond market expectations. They were also aware that privatisations undertaken in other jurisdictions changed management, a position affirmed by Claessens and Djankov (2000). Operating environment at eight (8) percent was one of the major drivers for financial performance. Cost reductions across the value chains were also adopted by all the four privatised companies and this driver was mentioned by fourteen (14) percent of the respondents.

According to Deloitte University Press (2016) executive leadership remains the top human capital resource and this called for leaders of the privatised firms to be globally aware, innovative, experienced in the business and above all ready to make decisions quickly with rigor. Not surprising that the same had up-scaled their business qualifications and redesigned their entire strategy for leadership development, driving deeper skills faster and building leadership at all levels on a continuous basis all for the purposes of driving improved financial performance. The analysis from the participants affirmed the hypothesis that management of the privatised companies had the capacity, vision and freedom to pursue profitable growth oriented policies that were to enable the firms to generate higher returns for investors. Improved corporate governance structures at company level in line with best practices and right-sized boards of directors who were appointed on merit but with requisite skills also helped to drive financial performance of the privatised companies. 
Table 5.1 shows the percentage distribution of the major drivers for financial performance of the privatised companies.

\subsection{Increase in product range and improvement on customer service post privatisation}

Product development and innovation strategies were the avenues through which privatised companies achieved growth. RTG focused on promoting domestic tourism: a territory that was previously ignored in favour of international tourism. But the refurbishment of the hotels took longer to implement and regional expansion projects in Mozambique and Zambia drained resources from the parent company. Standards became a nightmare to maintain. Cottco looked at exports of stock-feed meal products to South Africa and Botswana. Zimre introduced new short term insurance and life assurance products. Dairibord exited Uganda market due to viability challenges and its Malawi operations remained a struggle. The regional expansionist strategy involved higher risks than local market penetration strategies.

However, from 2012-14 Cottco lost a large base of its cotton growing farmers to competing merchants due to sidemarketing and improved logistical services by its competitors. Cottco's response strategy to that challenge was weakened by its mounting liquidity constrains. There are strong arguments to support that both Dairibord and RTG in their operational weaknesses created huge market opportunities for the entry of formidable competitors into their respective dairy and tourism sectors. Although privatised companies witnessed increases in product development, the research findings showed that fifty five (55) percent of the respondents reported a significant shortfall on customer service improvement and market share. Thirty six (36) percent agreed that the four privatised entities had lost some degree of their market share and nine (9) percent were not sure. Any privatisation has implications that will affect the performance of sector rivals through industrial re-positioning of the firms to capture and retain market share. From this stand point it is not surprising therefore that privatisation did not improve market share of the privatised companies in Zimbabwe.

\subsection{Investment in research and development $(R \& D)$ and technology by privatised companies}

Fifty four (54) percent of the participants indicated that the privatised entities engaged in R\&D while twenty (20) percent did not know the state of affairs. Those respondents, who answered in the negative, constituted twenty six (26) percent. Information on investment in R\&D helped privatised companies to keep abreast with global technological trends and changing customers' tastes. Of all the four privatised companies Cottco did not have a budget for R\&D and so lagged behind as dynamics in its industry changed. This lack of dynamism and failure to read unfolding events in the environment had a major impact on its continued financial difficulties. For Dairibord and Zimre and to a lesser extent RTG innovation and advancement in technology arising from the positive impacts of $R \& D$, were areas of major focus. The said companies long understood that being innovative was a necessity for being competitive and surviving the ever changing global landscape. The researcher is of the view that besides being research oriented organisations, the major drawback was that the privatised companies lacked benchmark for measuring innovation.

\subsection{Employee welfare improvements after privatisation}

The research findings showed that after privatisation there were generally welfare improvements on the workforce and this position was endorsed by seventy (70) percent of the respondents compared to thirty (30) percent who reported that employee benefits did not improve. Due to financial ill health, Cottco could not sustain welfare improvements it had introduced during its peak performance period. Added to this challenge the company had a bloated headcount. The majority of the respondents claimed that they were working harder than before and also reported more job satisfaction arising from periodical performance appraisals, career opportunities, increased salaries in line with additional responsibilities, improved working environment, robust systems of talent management, introduction of health and funeral cover, educational financial assistance, the introduction of transport, housing and technical allowances and periodical provision of uniforms. The rare opportunities for secondment to regional operations (before their demise) were mentioned as positive outcomes.

However, there were some participants who felt that the welfare of the workforce had not improved citing strict disciplinary processes which had been put in place after privatisation. Others complained about the companies' decision to stop providing subsidised loans to buy houses and vehicles despite mechanisms having been put in place at various providers of long term finance. Having aired all the negative aspects, the participants were appreciative of their employer's decision to continue supporting canteen operational activities. The responses from the participants presented both an opportunity and a challenge. An opportunity to recognise employees as an asset that contributes directly to company performance and a challenge to develop skills necessary to manage unrealistic expectations from the workforce. 


\subsection{Employment contracts for senior management}

All respondents at one hundred (100) percent affirmed that the contracts of senior management must be performance and term based. An unfixed term may breed corruption due to over-familiarisation with stakeholders and does not give room for innovative ideas required for the strategic thrust and policy leadership. The participants expressed the view that where the performance of privatised entities fell repeatedly short of the target threshold, disciplining management in terms of salary cuts or outright dismissal should be effected regardless of whether or not management were part of the ownership structure.

Performance and term based contracts for senior management which may be renewable once is the way to go. Those who lack the capacity to perform efficiently and fail to deliver the set targets should not survive but shown the exit door. The boards of directors must not mislead shareholders and the stakeholders into believing that the sacked CEO left the company to pursue personal interests when in actual fact the incumbent was thrown out on account of poor performance (Nguwi, 2016). However, in the real world a board is likely to give more leeway to a CEO who demonstrates the commitment to being accountable and deliver on their promises. Poorly crafted performance contracts are unlikely to yield good results unless they are properly crafted with realistic targets. The selected goals and objectives must be motivational and represent sustainable performance (Hall et al. (2016). In this regard the board must be strengthened in its capacity to negotiate robust employment contracts that reflect strong links between performance and remuneration.

No tolerance should be given to blaming the environment for the failure to achieve agreed targets. In Zimbabwe the CEOs of many companies (privatised entities included) have the tendency to blame the environment and lack of resources for the underperformance but equally surprisingly management forgets that part of being at the helm includes looking for resources for the organisation to function effectively (Nguwi, 2017). Zimbabwean privatised companies had, at the time of the study, some of the longest serving CEOs. While acknowledging CEOs' positive contributions, (for example, the Group CEOs of Zimre (now retired) and Dairibord still in office but with over 30 years of service pre and post privatisation) this position ignited talk about the importance of succession planning. Admittedly, the business landscape in Zimbabwe is unstable and continues to evolve. Harvard Business Review (2013) established that long CEOs tenures can hurt performance with regards to customer relationships, gathering market information and sustaining well- crafted strategies. CEOs tend to be less value adding to entities the longer they stay with the same organisation and can even end up being liabilities in terms of the need to be innovative in a changing environment.

Sometimes when management overstays at one company (and Zimbabwe witnessed a few of such ugly cases), three things are likely to happen. Firstly, deficiencies in corporate governance start to creep in thereby triggering the deterioration of company performance. When management are entrenched in a company, the temptation to appropriate shareholders' value to themselves is high (Charan, 2005). Hence, this is a major business risk. Secondly, cronies of management could easily find their way to the boardroom thereby reducing its effectiveness and increasing conflict of interest. Thirdly, directors who join the board in this awkward manner do not often have the courage to articulate dissenting viewpoint and they also lack the humility to know when their contribution is not the consensus (Charan, 2005). Fortunately there was no evidence to suggest that Zimbabwean privatised companies went through the three named curves.

Charan (2005) reports that in the first world CEOs rarely keep their positions for longer than two, five year terms. Their attachment to the status quo makes them less responsive to vacillating consumer preferences (Rhode and Packel, 2014). However, the flipside of having an entrenched CEO (and this argument does not have shelf life) is that if well incentivised probably through share options or hefty bonus, their interests become aligned with those of shareholders thereby acting in the interest of stakeholders in particular shareholders. Whichever route is taken, there will always be the need to put in place an effective board of directors that will keep management powers under check. Poor monitoring of the investment by both shareholders and directors tends to give the CEO too much power. Boards should be aware that long tenured CEOs may be great motivators to the employees but weak strategists unifying workers around a failing course of action (Rhode and Packel, 2014). The issue of succession planning which used to be viewed as being sacred within the corridors of corporate power should be openly debated for the good of the enterprise (Larcker and Tayan, 2016).

\subsection{Policy on gender and ethnicity diversity}

The majority at eighty two (82) percent of the respondents reported that the privatised companies had no policy in place on gender, age and ethnicity diversity compared to eighteen (18) percent who advised that they did have a policy in place. The principal argument in favour of diversity is the wide range of perspectives that each individual would bring to the boardroom table. This means the status quo is constantly challenged and critically reassessed giving way to innovative thoughts (Pierce, 2016). 
The study revealed huge disparity in female directors on the boards of privatised firms. Each company had one female director and in the researcher's view this was just a token and much less than their male counter parts. Only one privatised company, RTG, had a female chairperson. The board of Zimre Property, a subsidiary of Zimre, was chaired by a female director.

Myriad research confirms that having women on boards adds immense value and improves corporate performance in quantifiable ways (Teigland 2012). This thinking is also affirmed by McKinsey (2018) when their research team (Hunt, et al. 2018) revealed that gender diversity is correlated with both profitability and value creation. The research by Adams and Ferreira (2008) also identified that female directors had better attendance of board meetings and male directors had also better attendance when boards are more gender diverse.

Rhode and Packel (2014) state that diversity could help boards of privatised companies overcome tendencies toward group-think in which directors reach consensus too quickly because of the way social similarities shape their perception and decision making. The same authors argue that it can also encourage healthy debate by making directors more likely to challenge one another's viewpoints without excessive concern for maintaining harmony because of social similarity. From public policy's standpoint diversity is an important social value and one that is consistent with equality and this line of argument is also supported by Larcker and Tayan (2016).

While boards of the four privatised companies in Zimbabwe largely embraced gender diversity (by having at least one female board member as already mentioned), the researcher stresses that besides gender, diversity in its many forms including differences in age, background, ethnicity, nationality, professional experience and training is a critical component in a high-performing board (Teigland 2012). Unfortunately this type of diversity did not feature in the privatised companies. By way of comparison, Norway and Sweden with boards comprising twenty (20) percent of female directors are the front runners on gender diversity (Rhode and Packel, 2014).

Larcker and Tayan (2016) point out that ethnic diversity might improve decision making by ensuring that the board has the full array of knowledge in terms of market dynamics, customer behaviour and employee concerns to succeed operationally and culturally. The main point that is coming out of this discussion is that there is a growing body of research which shows that gender diversity is positively associated with financial performance and shareholder value. However, if improperly managed, board diversity may take time for board members to earn each other's trust in decision making as each person comes with a unique approach and perspective.

\subsection{Respondents' views on the successfulness of the privatisation programme}

The research findings showed that about eighty nine (89) percent of respondents affirmed that the privatisation programme was a success and hoped that it would be put back in motion while eleven (11) percent held a different view. The general objectives of promoting economic empowerment through privatisation of the four SOEs were met and all the companies survived and grew both organically and through acquisition strategies. At its peak Cottco bought controlling interests in other businesses but later disposed them when the going got really tough.

\subsection{Are political support and legal framework necessary for the successful implementation of the privatisation programme?}

Ninety-seven (97) percent of the respondents reported that political support and legal framework were necessary for the successful implementation of privatisation programme while three (3) percent saw things differently. In Zimbabwe lack of consensus and appreciation of the benefits of privatisation at the highest office during Mugabe's administration were the major factors that inhibited the privatisation pace. Mutugi and Ngugi (2013) point out that privatisation is not only an economic issue but also a political one. Political interest groups in Zimbabwe play a pivotal role in the affirmation or rejection of implementing the privatisation programme. There must be political will and commitment to walk the talk. Another driving force against the implementation of privatisation in Zimbabwe could be the fear to sell off family jewels to unknown personalities, institutions and hostile nationalities. Zimbabwe's privatisation programme, if ever it is revisited (and for the sake of good order it must be revisited), should be accompanied by a properly crafted legal framework. The absence of the legal framework creates enormous challenges around political commitment (lack of thereof), transparency and accountability. The experiences of both developed and developing countries suggest that without the necessary legal framework, privatisation process can also prove susceptible to manipulation enabling vested interest groups to gain control of a substantial part of the economy.

\subsection{Privatisation experiences from other African countries}

Ninety nine (99) percent of the respondents believed that Zimbabwe could benefit immensely from the experiences of other countries such as Zambia and Kenya which have gone through privatisation programmes. Critics often ask: Why should Zimbabwe re-invent the wheel when one has already been invented by others? 
The important lessons for Zimbabwe are: the need for restructuring the entities before their privatisation is a viable proposition as this approach puts the entity awaiting privatisation on well-grounded position; the programme must be open and transparent in ways which build confidence to the investing public whether local or foreign. That way, it sends the message of what to expect and also that the government is committed and wants the process to succeed; and financial support from various international developmental agencies to fund the privatisation programme as was the case with Kenya (Massey, 2010). In this regard, Zimbabwe should improve her international relations with various foreign governments.

The researcher points out that the results of the study per the above discussed statistical analysis are collaborative of the findings of the research using secondary data.

\subsection{Non-Parametric Hypothesis Testing}

\section{Table 6.10: Chi-Square Testing for Independence of Association}

\author{
Hypothesis \\ Ho: Privatisation of SOE's has not increased company profitability

\section{Pearson's Chi-Square} \\ 0.04
}

0.07

0.04

0.00

H1:Privatisation of SOE's has increased company profitability
Ho: Privatisation of SOE's has not advanced company technology

H1:Privatisation of SOE's has advanced company technology

Ho: Privatisation of SOE's has not increased employee benefits

H1:Privatisation of SOE's has increased employee benefits

Ho: Privatisation of SOE's has not increased company market share

\section{Decision}

Since the probability value is less than 0.05 , the researcher rejects the null hypothesis and concludes that there is indeed sufficient statistical evidence to conclude that privatisation increased company profitability.

\begin{abstract}
Since the probability value is more than 0.05 , we reject the null hypothesis and conclude that there is indeed sufficient statistical evidence to conclude that privatisation advanced company technology.
\end{abstract}

Since the probability value is less than 0.05 , we reject the null hypothesis and conclude that there is indeed sufficient statistical evidence to conclude that privatisation increased employee benefits. Since the probability value is less
than 0.05 , we accept the null
hypothesis and conclude that
there is indeed sufficient
statistical evidence to conclude
that privatisation did not increase
company market share.

H1:Privatisation of SOE's has increased company market share

\subsection{Survey Results from Secondary Data-Documentary Analysis}

In this second section the researcher presents and discusses the survey results from the four privatised companies obtained from the audited annual reports using four performance measurements: profitability, liquidity, gearing and efficiency ratios. Ratio analysis directs attention to potential areas of concern and a single ratio does not generally provide sufficient information from which to judge the overall performance of the company (Gitman, 2006). The study not only showed the financial performance of each privatised company but also carried out a comparative analysis of their performance levels over a six year period from 2009-14. What is the key from the analysed secondary data is that all the four privatised companies are still in business having withered the storm, admittedly, at varying degrees of success. 


\subsection{Profitability ratios}

According to Brealey et al. (2016) profitability ratios are used to judge how efficiently or inefficiently the company is using its resources (assets).

\subsubsection{Profit / (loss): 2009-14}

Table 5.2a shows the comparative profit / (loss) for each of the four privatised companies over the same period to December 2014. Dairibord recorded profitable results from 2009-12 and 2014. However, 2013 was a difficult year for the company because it incurred a loss of (USD1.753 million). The company's cumulative profit for the six year trading period totalled USD22.463 million and that positive result was ahead of the other three privatised companies by a wide margin. This remarkable financial performance by Dairibord demonstrates the argument that the company has strong and effective leadership whose understanding of the business and its dynamics are great sources of competitive advantage. The mean net profit margin for the whole period was 4.7 percent. RTG incurred losses from 2010-12 and 2014. However, the group reported profits in 2009 and 2013 resulting in accumulated losses of (USD7.163 million) as at 2014. The mean net profit margin for RTG in respect of the period under review was a negative 4.7 percent. Refer to Table 5.2b.

The trading results for Cottco reflected generally a downward trend from profits of USD15,326 million, USD17,479 million and USD14,848 million from 2009-11 to losses incurred by the company amounting to (USD2,091 million), (USD22,371 million) and (USD30,042 million) in respect of 2012-14 respectively. The increase in losses incurred by Cottco was in sympathy with significant reductions in turnover from 2012-14. Added to that problem was the company's failure to contain expenditure in tandem with reduced operational activities. The company's cost to income ratio moved from 80 percent to a mean of 458 percent and this development was financially disastrous for Cottco. Refer to Table 5.9 for the comparative cost to income ratios. By the end of 2014 Cottco had accumulated huge debts amounting to USD55 million despite the capital injection of USD45 million in 2013 which came from investments disposal proceeds. That negative positioncrippled Cottco's operations thereby making it technically insolvent. Were it not for the GOZ's intervention through re-nationalisation strategy when the company went into administration (business rescue), Cottco could have gone under and in the process exposing agricultural funders to huge financial losses.

Zimre's financial performance for the period to 2014 overall painted a good picture. The Group recorded profitable results for the four year period from 2009-13. However, in 2014 as reflected on Table 5.2a Zimre incurred a loss of (USD3.930 million) and this brought total earnings for the six year period to USD9.913 million.

\subsubsection{Return on total assets (ROA)}

According to Brealey et al. (2016) the return on total assets measures the overall effectiveness of management in generating profits with its available assets. The higher the firm's return on total assets, the better it is. Table 5.3 shows the comparative mean return on assets for all the four privatised companies. In analysing the financial performance of all the four privatised companies for the six years from 2009-14, Dairibord achieved the highest mean ROA at 6,2 percent and Zimre at 1,4 percent came second and these values indicate that the two entities earned 6,2 cents and 1,4 cents respectively on each USD of asset investment. The converse is true for RTG and Cottco because their mean returns on assets were negative at $(2,6)$ percent and $(10,7)$ percent respectively. The outcomes of the mean ROA on each privatised entity are in line with the net profits / (losses) generated and reported in Table 5.2b.

\subsubsection{Return on equity (ROE)}

The return on equity (which is the true bottom-line measure of performance) measures the return on shareholders' investment in the firm (Brealey et al. 2016). Table 5.4 shows the comparative mean ROE for the privatised companies.

Dairibord's mean ROE at 9, 3 percent over a six year period was the highest followed in second place by Zimre with a mean ROE ratio of 2,3 percent. The significance of the ratio is that for every USD in equity Dairibord and Zimre generated 9,3 cents and 2,3 cents in profit respectively. However, the outcomes for the other two privatised companies tell a different but disturbing story. For every USD in equity, RTG and Cottco generated losses amounting to (10,4 cents) and (9,5 cents) respectively and these outcomes were consistent with their reported poor financial performances. In this regard, Cottco had the worst negative return on equity and such poor performance precipitated its insolvent position. In analysing the returns for the privatised companies in Zimbabwe the researcher found it necessary to look at developments in South Africa, a country whose economic operating environment was not as harsh as Zimbabwe but was experiencing turmoil in debates around political leadership and state capture. 
According to Standard and Poor 500 (S\&P 500), the rate of return on investment for 2014 averaged at 8 percent (Peter the Planner, 2014). It was Dairibord at 9,3 percent that surpassed the S\&P 500 threshold. Although Zimre recorded a positive rate of return, it fell short of the average rating.

\subsubsection{DuPont return on assets (DuPont)}

According to Gitman (2006) DuPont is used to dissect the firm's financial statements and to assess its financial condition. DuPont shows that ROE depends on the firm's profitability, the management of its assets and the extent to which financial leverage is used (Ross et al. 1999). Returns emanating from asset turnover and profit margin are favoured as it means the returns are from sweating of assets and operational efficiency as opposed to more debt which is risky if the companies are already adequately leveraged. In order to analyse in detail the source of return on equity, the DuPont analysis is applied. As shown in Table 5.5 Dairibord and Zimre achieved the highest positive mean DuPont rate of 9,3 percent and 2,2 percent respectively. On the other hand, RTG and Cottco recorded negative mean DuPont rates of $(10,3)$ percent and $(417,9)$ percent respectively that were in sync with their achieved negative rates of return on equity. This outcome reinforced the poor financial performance for these two privatised companies during the greater part of the period under study. Cottco had lots of idle assets: ginneries in working order but not to use, unoccupied houses and empty warehouses all in outlying areas but could have been leased out. The advantage of using the DuPont is that management is able to trace backwards to identify those ratios where improvement can be achieved (Gitman, 2006).

\subsection{Liquidity ratios}

The researcher would like to stress that the common precursor to financial distress and perhaps bankruptcy of an entity is declining liquidity as current and quick asset ratios can provide early signs of cash flow difficulties (Brealeyet al. 2016: Ross et al. 1999). Tables 5a and 5b show that over the six year period from 2009-14 none of the privatised entities attained a current ratio of 2 which is often cited as an acceptable outcome and is therefore the benchmark. Dairibord had the highest mean current ratio of 1,5 ahead of Zimre and Cottco both at 1.2 each. Being a manufacturer of dairy products and beverages, Dairibord had the highest inventories figure. Zimre's liquidity position at current and quick asset ratio of 1,2 and 1,1 respectively was better than the rest. Dairibord's quick asset ratio at 0,8 was second. However, RTG's mean current and quick asset ratios were respectively the lowest at 0,7 and 0,6 during the same comparative trading period. Both ratios underscored the cash flow difficulties RTG experienced in its operations. With the exception of Zimre, a service industry player, none of the entities achieved the benchmark.

\subsubsection{Gearing ratios}

According to Gitman (2006) the more debt a firm uses in relation to its total assets or equity, the greater its financial leverage. While financial leverage increases the potential reward to shareholders, it also increases the potential distress and business failure. The case in point is that of Cottco where its debt equity ratio rose from 28,6 percent in 2009 to 97,2 percent in 2014 resulting in mean outcome of 54,8 percent. The upward trend in the debt equity ratio painted a picture of a struggling company and indeed profitability and efficiency ratios confirmed that position. RTG was another company which witnessed increased debt equity ratio from 6,1percent in 2009 to 58,3 percent in 2014 resulting in mean result of 43,8 percent. The mean debt equity ratio for Zimre was in the negative $(16,7)$ percent. Dairibord's mean debt ratio was 10,3 percent. The target gearing ratio for companies is 50 percent (Brealey et al. 2016).

\subsubsection{Debt ratio}

The higher the debt ratio, the greater the firms' degree of indebtedness and the more financial leverage the privatised companies had. Table 5.7 shows that of the four privatised entities Dairibord had the lowest mean debt ratio of 34,1 percent followed by Zimre at 36,9 percent.

Meanwhile, the mean debt ratios for Cottco and RTG for the comparative period to 2014 were 64 percent and 63,7 percent respectively. The values indicated that both companies had financed close to two thirds of their assets with debt. In bringing out the extent of Cottco's indebtedness, the researcher points out that in 2014 the company's debt ratio reached 97,8 percent, an alarming figure by any measure. The researcher underscores the fact that debt affects the company's capacity not to service the debt!

\subsection{Efficiency ratios}

These ratios are used to analyse how well a company uses its assets and liabilities internally. In the analysis of operational efficiencies of the privatised companies, this study used two ratios namely the Jaws and cost to income.

\subsubsection{Jaws Ratio}


The researcher brings on board the importance of the Jaws Ratio (JR) in reviewing the financial performance of the privatised companies. Gitman (2006) asserts that the JR is a measure used in finance to demonstrate the extent to which a trading entity's income growth rate exceeds its expense growth rate, measured as a percentage and is calculated as follows: Jaws Ratio $=$ Income growth rate - Expense growth rate

The JR is significant in that a larger positive value demonstrates that the company is effectively generating more income over time than it is generating expenses thereby potentially increasing its profitability and profitability growth rate. Therefore a JR above the zero percentage horizontal axis indicates a positive trend for the company whilst below zero indicates a negative trend (Gitman, 2006). Table 5.8 depicts that Zimre had the highest mean JR at 0,9 percent in relation to the other three privatised companies. RTG's JR outcome at a mean of $(3,1)$ percent was the second and higher than Dairibord which achieved a mean JR of $(3,6)$ percent. Cottco registered an outrageous negative JR of $(30,5)$ percent. The JRs reinforced the extent to which the operating environment in Zimbabwe was difficult at that time.

\subsubsection{Cost to income ratio (CIR)}

Table 5.9 depicts the mean cost to income ratio for the four privatised companies. The two privatised companies which reported mean cost to income ratio (CIR) below 100 percent were Dairibord and Zimre at 84,9 percent and 97,3 percent respectively. The mean CIRs for RTG and Cottco from 2009-14 were 107,1 percent and 457,7 percent respectively and such high figures had a major impact on the poor financial position of those two companies. The important key to note is that high CIR spells disaster for the financial performance of a business and it would be impossible to sustain operations under such high expenditure regime. As part of their commitment to survive and sustain operations, all the privatised companies adopted cost containment strategies in response to declining economic activities. Such critical measures created capacity constrain on the part of the privatised companies to continue offering some welfare benefits to the workforce.

\subsection{Conclusion, Policy Implication and Recommendations}

Business is a rocky road and progress is uneven. This research study breaks new ground and interesting observations emerged from the results. While acknowledging that the number of privatised companies was low, the results of the research study on the four privatised companies in Zimbabwe demonstrated that privatisation resulted in enhanced company profitability, advanced company technology and increased employee welfare and benefits. However, the same did not increase company market share. The results of this study complement the empirical studies done by various scholars including Radygin et al. (2015): Anuatti-Neto et al. (2005): Boubakri and Cosset, 2002, (1998); Eckel et al. (1997): Megginson et al. (1994): Vickers and Yarrow (1997). Dairibord and Zimre were good performers. Both had stability at the top and benefited greatly from their long serving CEOs although critics would sing a different tune. RTG struggled but nowhere near Cottco whose poor financial performance from 201114 severely threatened its going concern status. In the economic jungle there will always be elephants, lions, leopards, hyenas and snakes yet through the years, the balance of nature has somehow been and should be preserved except in extreme cases where government and other outside influences have interferred. This scenario resembles very much the outcome of the study as stated above. A very pertinent challenge that the study also identified was the failure by both management and the board to grasp changes in the economic and social environment and this outcome is more pronounced in Cottco than the other three privatised companies.

The researcher believes that the continuation of ownership of non-strategic entities by the GOZ is not a viable proposition in today's world.

According to El-Rufai (2012) state capitalism assumes a competent government that has proven its capacity to deliver basic social services (security, infrastructural development, education, clean water and health care). Such a government could run economic enterprises with degree of success under certain conditions. The researcher knows the extent to which Zimbabwe has experienced severe economic and social difficulties and he therefore questions the government's capacity to continue being an economic entrepreneur outside strategic industries. The appetite by the GOZ to sell national assets through privatisation often disappears once a crisis has passed and this response strategy could explain why privatisation has not been accelerated. What sort of leadership is required for privatised companies? This could be an area for further research.

The total number of privatised companies in Zimbabwe which stood at five (but the research study worked on four entities as fully explained in the sub-heading 1.4) may not be large enough to allow a full statistical analysis. The inability to measure this effect in this study is a limitation. Perhaps, this is one area where future research can be undertaken in Zimbabwe to cover more companies when privatisation of SOEs is undertaken on a large scale. Despite this possible minor limitation the same pattern emerged from the study of four privatised entities. 


\section{References}

Abu Shair, O.J.A.R. (1997). Privatization and Development. Macmillan Press.

Adams, R. and Ferreira, D. (2008). Women in the Boardroom and their impact on Governance and Performance www.ssrn.org 2008 accessed 7 May 2017.

Andreff, W. (1997): Privatization and Corporate Governance in Transition Countries: Beyond the Principal-Agent Model. In E. F. Rosenbaum, F. Bonker and H. J. Wagener (eds.), Privatization, Corporate Governance and the Emergence of Markets(pp 123-138). Macmillan Press.

Ary, D., Jacobs, L. C. \& Razavieh, A. (2002). Introduction to Research in Education.Wadsworth / Thomson Learning.

BA Case Study: www.academic.edu Accessed 2 September 2014.

Bernard, H. R. (2013). Social Research Methods: Qualitative and Quantitative Approaches. (2 ${ }^{\text {nd }}$ ed). Sage Publications.

Blair, D. (2002). Degrees in Violence: Robert Mugabe and the Struggle for Power in Zimbabwe. Continuum.

Boubakri, N. \& Cosset, J. C. (2002). Does Privatisation Meet the Expectations in Developing Countries? A Survey and Some Evidence from Africa. Oxford Journals: Journal of African Economies, Volume 11 Issue Supplement pp 111-140.

Boubakri, N. \& Cosset, J.C. (1998). The Financial and Operating Performance of Newly Privatised Firms: Evidence from Developing Countries. Journal of Finance 53, Number 3, June 1998 pp 1081-1100.

Bradshaw, B. (2000). New Directions for Britain's Railways.In R. Freeman \& J. Shaw (Eds), All Change: British Railway Privatisation (pp 229-242).The McGraw-Hill Companies.

Brealey, R. A., Myers, S.R. \& Allen, F. (2016). Principles of Corporate Finance.(12 ${ }^{\text {th }}$ ed).McGraw-Hill.

British Airways PLC Annual Report and Accounts for the year ended 31 December 2012/ 2013.

British Airways: https// www.britishairways.com Accessed 6 August 2013.

Burnes, B. (2004). Managing Change:A Strategic Approach to Organisational Dynamics. ( ${ }^{\text {rd }}$ ed)Financial TimesPrentice Hall.

Charan, R. (2005). Boards that Deliver: Advancing Corporate Governance from Compliance and Competitive Advantage. Jossey-Bass, Wiley Imprint.

Chen, G., Firth, M. and Rui, O, (2006). Have China's Enterprise Reforms Led to Improved Efficiency and Profitability for Privatised SOEs? Emerging Markets Review 2006, Elsevier.

Chipwende, A. (2001). Written responses to request for information on Zambian privatisation programme.

Chipwende, A. (1999). The Zambian Experience with Privatisation. In J. Kateera (Ed), The Way Forward Commercialisation, Privatisation Techniques and Financing Options (pp33-36).Friedrich-Ebert-Stiftung.

Claessen, S. and Djankov, S. (2000). Manager Incentives and Turnover of Managers:Evidence from the Czech Republic. In E. F. Rosenbaum, F. Bonker, and H. J. Wagener (Eds), Privatization, Corporate Governance and the Emergence of Markets pp 171-188). Macmillan Press.

Cook, P. and Uchida, Y. (2003). Privatisation and Economic Growth in Developing Countries: The Journal of Development Studies.

Debrah, Y. A. and Toroitich, O. K. (2005). The making of an African success story: The privatization of Kenya Airways: Thunderbird International Business Review, Volume 47, Issue 2, March/April 2005, pp 205-230.

http://www2.deloitte.com/us/en/pages/centre-for-corporate-governance/Articles/on-the-board 2/16/2016On the Board's Agenda |US Board composition: Greater than the sum of its parts Accessed July 2016.

Dewenter, K. and Malatesta, P. (2001).State-Owned and Privately Owned Firms: An Empirical Analysis of Profitability, Leverage and Labour Intensity: American Economic Review 91 (1) pp 320-334.

Dutra, A, (2012). A More Effective Board of Directors: https://hbr.org/2012/11/a-more-effective-board-of-dire.

Eckel, C., Eckel, D. and Singal, V. (1997). Privatisation and Efficiency: Industry Effects of the Sale of British Airways. Journal of Financial Economics 43, 1997 pp 275-298.

El-Rufai, N. (2012). Privatisation in Nigeria: The Promise, The Peril. $52^{\text {nd }}$ Independence Anniversary Special Edition 3 October 2012.

Fitzroy, P., Hulbert, J. M. and Ghobadian, A. (2012). Strategic Management: The Challenge of Creating Value. $\left(2^{\text {nd }}\right.$ ed). Routledge, Taylor and Francis Group.

Francies, J. and Tufali, A. (1998). Impact of Privatization in Pakistan: Final Report-Volume Two-The Case Studies. Asian Development Bank.

Gitman, L.J. (2006). Principles of Managerial Finance.(11 ${ }^{\text {th }}$ ed), Pearson Addison Wesley.

Godana, T and Hlatshwayo, (1998). Public Enterprise Reform and Privatisation in Zimbabwe: Economic, Legal and Institutional Aspects, Zambezia XXV (1).

Grout, P. (1999). Popular Capitalism with Employee Buy-Outs. In M Bishop, J. Kay, J. \& C. Mayer (Eds), Privatization and Economic Performance.pp299-312 Oxford University Press. 
Gulf Business (2016). Air Seychelles appoints ex-Etihad official as new CEO. Accessed on 1 March 2016 at $10.25 \mathrm{am}$.

Haley, S. (1999). The Zambia Privatisation Experience: Lessons for Zimbabwe.InJ. Kateera (Ed),Privatisation: The Way Forward-Commercialisation, Privatisation Techniques and Financing Options.(pp 37-40). FriedrichEbert-Stiftung.

Hall, S., McCord, F. and Hall, S. Jr. (2016). The Effective Compensation Committee. In R.Leblanc (Ed), The Handbook Board Governance: A Comprehensive Guide for Public, Private and Not-For-Profit Board Members. John Wiley and Sons Inc.

Hoever, I. J., Van Knippenberg, D., Van Ginkel, W. P., \&Barkema, H. G. (2012).Fostering Team Creativity: Perspective Taking as Key to Unlocking Diversity's Potential. Journal of Applied Psychology, 9, 982.Doi: 10.1037/a002915.

Hopkin, P. (2012). Fundamentals of Risk Management: Understanding, evaluating and implementing effective risk management. $\left(2^{\text {nd }}\right.$ ed $)$, Kogan Page.

Jerome, A. (2004). Privatization and Regulation in South Africa: An Evaluation.......

Jones, L. (1994). Winners and Losers in Privatisation. In A. Galal, and M. Shirley (Eds), Does Privatisation Deliver?Highlights from a World Bank Conference (pp91-99). The World Bank.The International Bank for Reconstruction and Development.

Kaffenberger, W. E. (1995). Preface. In D. J. Donaldson and D. M. (principal authors), Privatization Principles and Practice: Lessons of Experience Series. International Finance Corporation.

Kay, J. and Thompson, D. (1986).Privatisation: A Policy in Search of a Rationale: The Economic Journal, 96 (381) pp18-32.

www.Kenyaairways corporate strategy. Accessed on 14/06/2014Kenya Airways official website

Kotler, P. \& Keller, K.L. (2011). Marketing Management. (14 ${ }^{\text {th }}$ ed). Pearson Educational.

Larcker, D. and Tayan, B, (2016). Corporate Governance Matters: A Closure Look at Organisational Choices and Their Consequences. $\left(2^{\text {nd }}\right.$ Ed). Pearson Education.

Leathley, A. (2000).Railtrack's Recent Performance. In R Freeman and J Shaw (Eds),All Change: British Railway Privatisation. (pp 83-96). The McGraw-Hill Companies.

Letwin, O. (1988). Privatising the World. Cassel Publications.

Lubansa, B. and Mofya, B. (2005). Healthcare Reforms in Zambia. In E. U. Weizasacker, O. Young \& M. Finger Limits to Privatization: How to Avoid Too Much of a Good Thing (pp137-140). Earthscan.

Makadho, J. (2006). Land Distribution Experiences in Zimbabwe 1998-2004 .In M. Rukuni, P. Tawonezvi, C. Eicher, with M. Munyuki-Hungwe, and P. Matondi, (Eds), Zimbabwe's Agricultural Revolution Revisited (pp165-188).University of Zimbabwe Publications.

Massey, A. (2010). Lessons from Africa: New Public Management and the Privatisation of Kenya Airways: Public Policy and Administration: 01/2010: pp 194-215 Dol: 10.1177 / 0952076709356860.

McKinsey (2018). Women in the Work Place 2019. McKinsey

Megginson, W. L. (1998). The Impact of Privatization: Economic Reform Today April 1998, Centre for International Private Enterprise.

Megginson, W. L. (2010). Privatisation and Finance: Annual Review of Financial Economics Journal 2 pp 145174.

Megginson, W. L, Nash, R.C and Van Randenborgh, M. (1998).The Financial and Operating Performance of Newly Privatised Firms: An International Empirical Analysis. Estudios de Administration, Vol. 5, Issue 1 pp 43-101.

Megginson, W. L. \& Netter, J. M. (2001). From State and Market: A Survey of Empirical Studies on Privatisation. Journal of Economic Literature Vol 39 pp 321-389.

Megyery, K. and Sadler, F. (1997). Facilitating Foreign Participation in Privatization. DOI: 10.1596/0-82133824-2:http:// elibrary.worldbank.org. Accessed 2 June 2016.

Miller, A. N. (1997). Ideological Motivations of Privatization in Great Britain versus Developing Countries. Journal of International Affairs, Vol 50 Issue 2 pp 391-407.

Mutugi, J. M.,and Ngugi, P. K. (2013). Effects of Privatisation on Performance of Privatised Public Enterprises Listed in the Nairobi Security Exchange in Kenya: A Survey of Privatised Firms in the Nairobi Security Exchange: International Journal of Innovative Research and Development. August 2013, Vol 2 Issue 8 pp 437-441. www.ijird.com. Accessed 6 November 2016.

Mwandenga, A.M. (1999). Socio-Economic Impact of Privatisation: The Tanzanian Experience. The African Journal of Finance and Management Vol 9 No 1 pp 44-57.

Naikuni, T (2004). How a Privatised Kenya Airways sees its role in building infrastructure for an East African Airports hub. $8^{\text {th }}$ ASEA Conference and Nairobi Stock Exchange Golden Jubilee Nairobi 23-26 November 2004. 
Nellis, J. R. (1986). Public Enterprises in Sub-Saharan Africa. World Bank Discussion Paper Number 1,World Bank.

Ochieng, M.D. (2014). The Effects of Privatisation on the Financial Performance of Kenya Airways. International Journal of Business and Commerce: Vol 3, No. 5: January 2014 pp 10-26.

Onwuegbuzie, A. J. and Leech, N.L. (2007). A Call for Qualitative Power Analyses.Quality and Quantity.Volume 41pp 105-121.

Oyieke, S. (2002).Kenya Airways: A Case Study of Privatisation. African Economic Research Consortium.

Paechter, C. (2013). Researching Sensitive Issues Online: Implications of a hybrid insider outsider position in a retrospective ethnographic study. Qualitative Research, 13, pp 71-86. Doi: 10.1177/1468794112446107.

Peter the Planner (2014). http:/peter the planner.com/wp-content/uploads/2013/01/SP500-1995-2014.jpg. Accessed on 25 May 2017.

Pettinger, T. (2013).Economic Impact of Margaret Thatcher: April 19, 2013 (http://www.economicshelp.org/blog/274/uk-economy/economic-impact-of-margaret- thatcher1) Accessed on 22 February 2017.

Pierce, C. (2016). Trends in Corporate Governance. In R. Leblanc (Ed), the Handbook Board Governance: A Comprehensive Guide for Public, Private and Not-For-Profit Board Members. John Wiley and Sons Inc. pp ---

Radygin, A., Simachev, Y. \& Entov, R. (2015). The State-Owned Company: "State Failure" or "Market Failure. "Russian Journal of Economics Vol 1, Issue 1, March 2015 pp55-80.https: do1.org/10.1016/j.ruje 2015.05.001 Accessed 5 December 2016.

Ramamurti, R. (1992). Why Are Developing Countries Privatizing? Journal of International Business Studies, Second Quarter, Volume 23, Issue 2 pp 1-17.

Reuters (2015). Kenya Airways Gets USD240 million in Loans from Government and African Export-Import Bank.: www.reuters.com>article>kenya-airways Accessed on 24/11/2015.

Rhode, D. L. and Packel, A. K. (2014). Diversity on Corporate Boards: How Much Difference Does 'Difference' Make? Delaware Journal of Corporate Law, Issue 39 pp 377-426.

Rivers, M. (2015). Kenya Airways in Freefall? African Business. November 2015, pp 46 and 47, IC Publications.

Ross, S.A., Westerfield, R. W., Jordan, B. D. and Firer, C. (1999). Fundamentals of Corporate Finance. $\left(1^{\text {st }}\right.$ South African ed), The McGraw-Hill Companies.

Sadler, F. (1995). Privatizing Public Enterprises and Foreign Investment in Developing Countries, 1988-1993. Foreign Investment Advisory Service, a joint facility of the International Finance Corporation and the World Bank. http://library.africa-union.org DO1:10.1596/0-8213-3362-3 Corpus ID: 55933468.

Saunders, P. and Harris, C. (1994). Privatization and Popular Capitalism, Open University Press.

Anuatti-Neto, F., Barossi-Filho, M., de Carvalho, A. G. \&Macedo, R. (2005). Costs and Benefits of Privatization: Evidence from Brazil.InA Chong \& F Lopez-de- Silanes(Eds),Privatization in Latin America: Myths and Reality (pp 145-196). Stanford University Press and The World Bank.

Shaw, J. (2000). Designing a Method of Rail Privatisation. In R. Freeman \& J Shaw (Eds),

All Change: British Railway Privatisation (pp 1-30). The McGraw-Hill Companies.

Suri, H. (2011). Purposeful Sampling in Qualitative Research Synthesis. Qualitative Research Journal, 11, 6375.doi:10.3316/DRJ1102063.

Tangri, R. (1999). The Politics of Patronage in Africa: Parastatals, Privatization and Private Enterprise. James Currey Limited.

Tanyi, G. B. (1997). Designing Privatization: Strategies in Africa: Law, Economics and Practice.Praeger Publishers.

Teigland, J.L. (2012). Time for Diversity: Accelerating Performance in Corporate Boardrooms. Credit Suisse Research Institute available at WWW.Credit-Suisse.Com Accessed on 20December 2014.

The Economist (2013). Freedom Fighter.13 April 2013 p9.

The Economist (2007). Northern Rock-Slouching Towards Nationalisation.22 December 2007 pp 43 and 44.

www.UKessays.com.the reasons as to why Kenya Airways was privatised.Accessed 14 June 2014

Vickers, J. \& Yarrow, G. (1997). Privatization: An Economic Analysis.The Massachusetts Institute of Technology.

Vogelsang, I. (1994). Approach and Case Studies: United Kingdom. In A. Galal and M. Shirley (Eds). Does Privatisation Deliver? Highlights from a World Bank Conference (pp 33-45).

World Bank (2002). Zambia: Privatization Review: Facts, Assessment and Lessons. World Bank.

Young, R.A. (1995). Privatisation: African Perspectives.In P. Cook and C. Kirkpatrick (Eds), Privatisation, Policy and Performance: International Perspectives. Prentice Hall / Harvester 


\section{FIGURES AND TABLES FROM THIS ARTICLE}

Figure 3.1 Conceptual Framework: Privatisation and its Impact

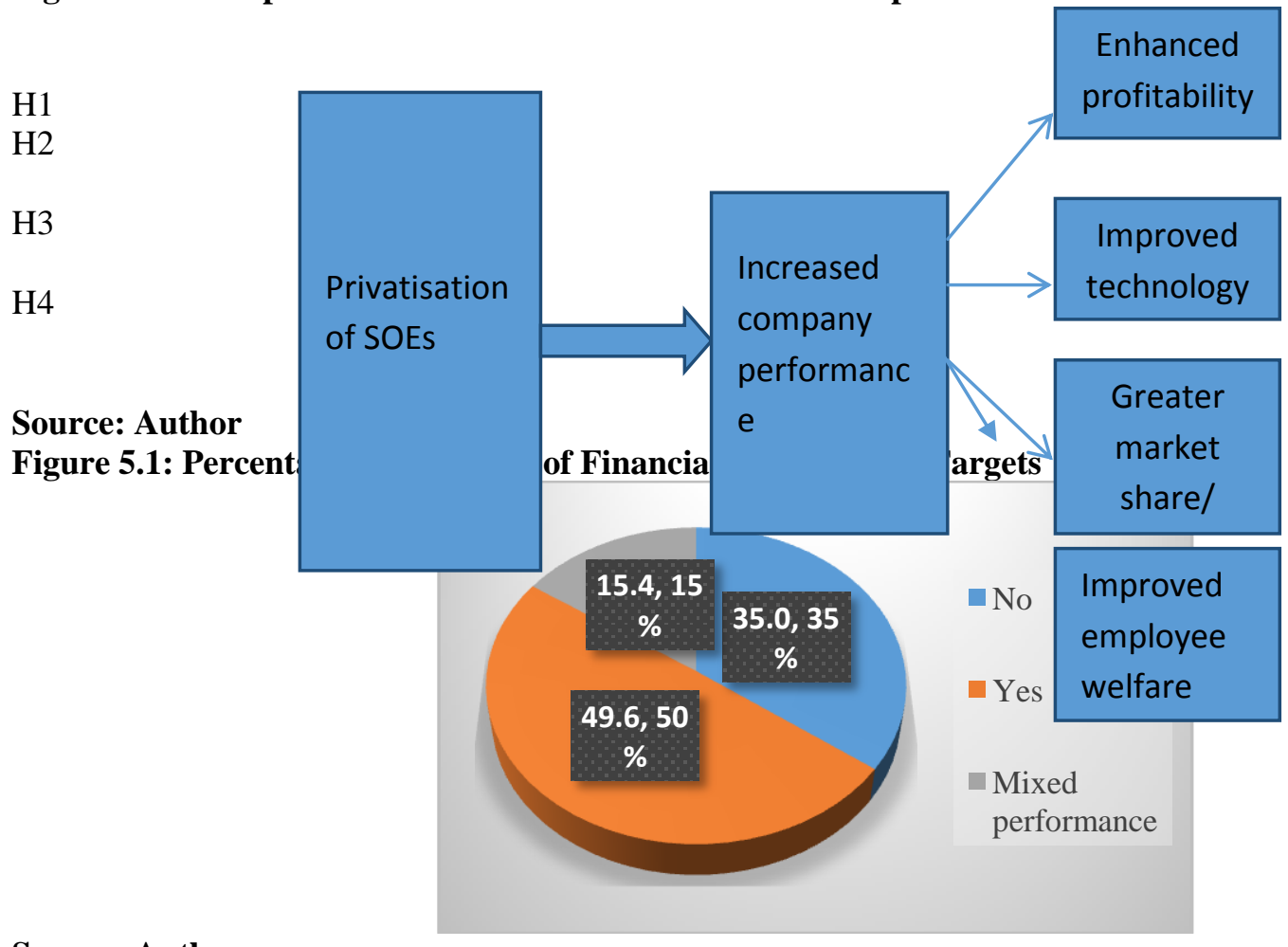

\section{Source: Author}

Table 5.1: Percentage Distribution of Major Driver for the Financial Performance of the Privatised Entities

\begin{tabular}{|c|c|}
\hline \multirow{3}{*}{ Major Driver } & Visionary leadership \\
\hline & Freedom board/management in running business \\
\hline & Cost Containment strategies \\
\hline & Operating environment \\
\hline & Total \\
\hline
\end{tabular}

\section{Source: Author}

Table 5.2a: Comparative Profit or (Loss): from 2009-14

\begin{tabular}{|c|c|c|c|c|c|c|c|}
\hline USD'000 & $\begin{array}{l}2009 \\
\text { \$ million }\end{array}$ & $\begin{array}{l}2010 \\
\text { \$ million }\end{array}$ & $\begin{array}{l}2011 \\
\text { \$ million }\end{array}$ & $\begin{array}{l}2012 \\
\text { \$ million }\end{array}$ & $\begin{array}{l}2013 \\
\text { \$ million }\end{array}$ & $\begin{array}{l}2014 \\
\text { \$ million }\end{array}$ & $\begin{array}{l}\text { Total } \\
\text { \$ million }\end{array}$ \\
\hline Dairibord & 3.096 & 6.142 & 7.187 & 7.187 & -1.753 & 0.604 & 22.463 \\
\hline RTG & 0.159 & -1.153 & -0.371 & -5.887 & 1.059 & -1.356 & -7.549 \\
\hline Cottco & 15.326 & 17.479 & 14.848 & -2.091 & -22.371 & -30.042 & -6.851 \\
\hline Zimre & 0.082 & 2.527 & 6.295 & 3.645 & 1.294 & -3.930 & 9.913 \\
\hline Total & 18.663 & 24.995 & 27.959 & 2.854 & -21.771 & -34.724 & 17.976 \\
\hline
\end{tabular}


Source: Author: Figures extracted from Annual Reports 2009-14

Table 5.2b: Comparative Profit / (Loss) Margin after Tax: from 2009-14

\begin{tabular}{lcccccccc} 
& \multirow{2}{2009}{} & $\mathbf{2 0 1 0}$ & $\mathbf{2 0 1 1}$ & $\mathbf{2 0 1 2}$ & $\mathbf{2 0 1 3}$ & $\mathbf{2 0 1 4}$ & \multicolumn{2}{c}{ Mean } \\
\hline Dairibord & 7.1 & 8.2 & 7.5 & 6.7 & -1.8 & \multicolumn{1}{c}{0.6} & \multicolumn{1}{c}{$\%$} \\
RTG & 0.9 & -5.6 & -1.4 & -21.4 & 3.6 & -4.4 & -4.7 \\
Cottco & 12.7 & 7.7 & 5.1 & -1.6 & -53.3 & -78.4 & -18.0 \\
Zimre & 0.2 & 6.2 & 12.6 & 4.7 & 1.7 & -5.3 & 3.4
\end{tabular}

Source: Author: Calculations based on figures extracted from Annual Reports 2009-14.

Table 5.3: Comparative Return on Assets (ROA): from 2009-14

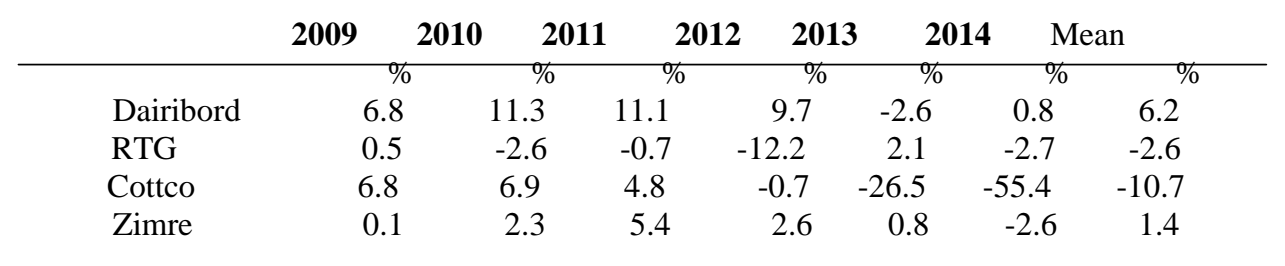

Source: Author: Calculations based on figures extracted from Annual Reports 2009 to 2014

Table 5.4: Comparative Return on Equity (ROE): from 2009-14

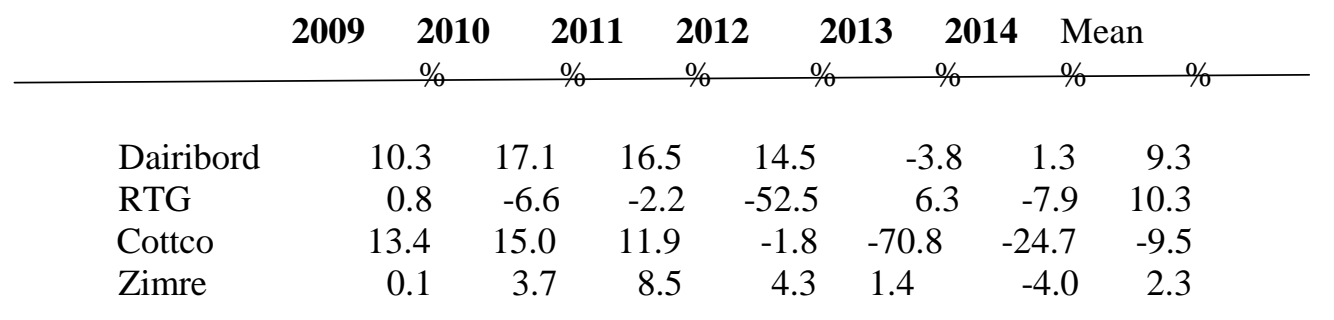

Source: Author: Calculations based on figures extracted from Annual Reports 2009 to 2014

Table 5.5: Comparative DuPont Return on Assets: from 2009-14

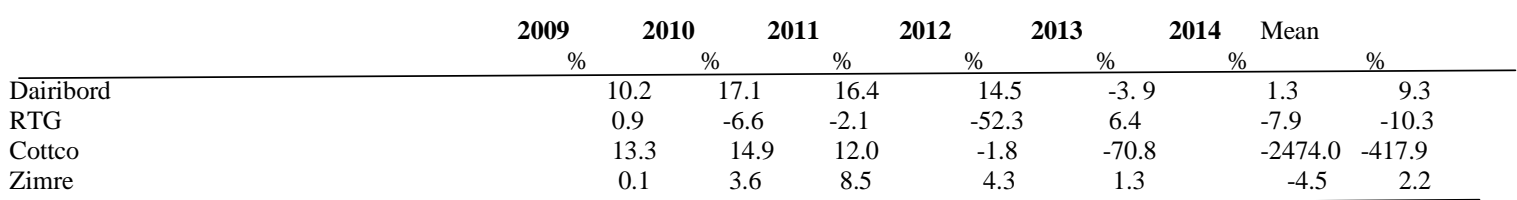

Source: Author: Calculations based on figures extracted from Annual Reports 2009 to 2014

Table 5.6a: Comparative Current Ratio: from 2009-14

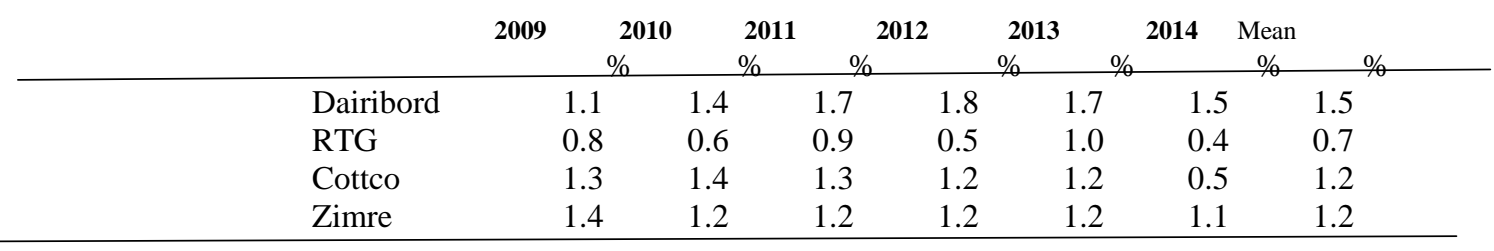

Source: Author: Calculations based on figures extracted from Annual Reports 2009 to 2014

Table 5.6b: Comparative Acid Test Ratio: from 2009-14

\begin{tabular}{llllllllll} 
& 2009 & $\mathbf{2 0 1 0}$ & $\mathbf{2 0 1 1}$ & $\mathbf{2 0 1 2}$ & $\mathbf{2 0 1 3}$ & $\mathbf{2 0 1 4}$ & \multicolumn{2}{c}{ Mean } & $\%$ \\
\hline Dairibord & 0.6 & 0.7 & 0.9 & 0.9 & 0.8 & 0.7 & 0.8 \\
RTG & 0.7 & 0.7 & 0.7 & 0.4 & 0.8 & 0.3 & 0.6 \\
Cottco & 0.8 & 0.9 & 0.8 & 0.8 & 0.6 & 0.2 & 0.7 \\
Zimre & 1.3 & 1.2 & 1.1 & 1.2 & 1.1 & 0.9 & 1.1 \\
\hline
\end{tabular}

Source: Author: Calculations based on figures extracted from Annual Reports 2009 to 2014 
Table 5.7: Comparative Debt Ratio

\begin{tabular}{llcccccccc} 
& $\mathbf{2 0 0 9}$ & $\mathbf{2 0 1 0}$ & $\mathbf{2 0 1 1}$ & $\mathbf{2 0 1 2}$ & $\mathbf{2 0 1 3}$ & $\mathbf{2 0 1 4}$ & \multicolumn{2}{c}{ Mean } \\
\hline Dairibord & 33.4 & 33.6 & 32.5 & 32.9 & 32.8 & 39.2 & 34.1 \\
RTG & 44.3 & 60.7 & 67.3 & 76.7 & 67.0 & 66.0 & 63.7 \\
Cottco & 49.0 & 53.7 & 60.1 & 60.7 & 62.6 & 97.8 & 64.0 \\
Zimre & 30.2 & 36.1 & 36.7 & 39.0 & 37.7 & 41.7 & 36.9
\end{tabular}

Source: Author: Calculations based on figures extracted from Annual Reperts 2009 to 2014

Table 5.8: Jaws Ratio: from 2009-14

\begin{tabular}{|c|c|c|c|c|c|c|c|}
\hline & & 2010 & 2011 & 2012 & 2013 & 014 & Mean \\
\hline DAIRIBORD & & $\%$ & $\%$ & $\%$ & $\%$ & $\%$ & $\%$ \\
\hline Income growth rate $(\%)$ & & 72.2 & 29.6 & 4.3 & -23.4 & -7.7 & 15.0 \\
\hline Expenditure growth rate $(\%)$ & & 68.7 & 28.6 & 8.5 & 4.6 & -17.2 & 18.6 \\
\hline Jaws ratio $(\%)$ & & 3.5 & 1.0 & -4.2 & -28 & 9.5 & -3.6 \\
\hline & & 2010 & 2011 & 2012 & 2013 & 2014 & Mean \\
\hline RTG & & $\%$ & & 70 & -70 & $\%$ & - 70 \\
\hline Income growth rate $(\%)$ & & 17.5 & 32.3 & 2.8 & 6.2 & -21.9 & 7.4 \\
\hline Expenditure growth rate $(\%)$ & & 36.6 & 14.4 & 22.5 & -13.8 & -7.2 & 10.5 \\
\hline Jaws ratio $(\%)$ & & -19.1 & 17.9 & -19.7 & 20.0 & -14.7 & -3.1 \\
\hline $2010 \quad 2011$ & 2012 & 2013 & 014 & Mean & & & \\
\hline COTTCO & & $\%$ & $\%$ & $\%$ & $\%$ & $\%$ & $\%$ \\
\hline Income growth rate $(\%)$ & & 25.0 & 4.7 & -58.2 & -92.2 & -73.4 & -38.8 \\
\hline Expenditure growth rate $(\%)$ & & 25.9 & 10.1 & -38.4 & -26.7 & -17.7 & -9.6 \\
\hline Jaws ratio $(\%)$ & & -0.9 & -5.4 & -19.8 & -65.5 & -55.7 & -29.4 \\
\hline $2010 \quad 2011$ & 2012 & 2013 & 2014 & Mean & & & \\
\hline ZIMRE & & $\%$ & $\%$ & $\%$ & $\%$ & $\%$ & $\%$ \\
\hline Income growth rate $(\%)$ & & -10.9 & 18.9 & 51.1 & 4.4 & -5.2 & 11.7 \\
\hline Expenditure growth rate $(\%)$ & & -2.0 & 13.6 & 62.6 & -20.0 & -0.4 & 10.8 \\
\hline Jaws ratio $(\%)$ & & -8.9 & 5.3 & -11.5 & 24.4 & -4.9 & 0.9 \\
\hline
\end{tabular}

Source: Author: Calculations based on figures extracted from Annual Reports 2009 to 2014

Table 5.9: Comparative Cost to Income Ratios: 2009 to 2014

\begin{tabular}{|c|c|c|c|c|c|c|c|}
\hline & $\begin{array}{c}2009 \\
\%\end{array}$ & $\begin{array}{c}2010 \\
\%\end{array}$ & $\begin{array}{c}2011 \\
\%\end{array}$ & $\begin{array}{c}2012 \\
\%\end{array}$ & $\begin{array}{c}2013 \\
\%\end{array}$ & $\begin{array}{c}2014 \\
\%\end{array}$ & $\begin{array}{c}\text { Mean } \\
\%\end{array}$ \\
\hline Dairibord & 77.3 & 75.8 & 75.8 & 78.3 & 106.9 & 95.9 & 84.9 \\
\hline RTG & 98.9 & 114.9 & 99.4 & 118.5 & 96.2 & 114.4 & 107.1 \\
\hline Cottco & 80.0 & 80.4 & 84.5 & 124.6 & 1163.4 & 1213.4 & 457.7 \\
\hline Zimre & 90.4 & 99.5 & 95.0 & 102.3 & 96.0 & 100.8 & 97.3 \\
\hline
\end{tabular}

Source: Author: Calculations based on figures extracted from Annual Reports 2009 to 2014 